\title{
ECLECTIC ART DECO IN SURAKARTA: COMPARISON OF THREE RESIDENCES IN SURAKARTA (LAWEYAN, BALUWARTI, KAUMAN)
}

\author{
Nafiah Solikhah ${ }^{1 *}$, Andi Surya Kurnia ${ }^{2}$, \\ ${ }^{1,2}$ Department of Architecture and Planning, Faculty of Engineering, Tarumanagara University, \\ Campus 1, L Building, 7th Floor, Jl. Let Jen. S. Parman Number 1, West Jakarta 11440, Indonesia \\ *Corresponding author; Email: nafiahs@ft.untar.ac.id
}

\begin{abstract}
Art Deco emerged from the change of thinking ways of a group of people who one of them backed from the establishment of the economy. In Surakarta, there are areas that get influence Art Deco style, among others: Baluwarti, Laweyan, and Kauman. The problem is the absorption and adaptation of elements of Javanese culture and other culture that produce different art deco typology in each object of study. This study aims to compare the absorption and adaptation of elements of Javanese culture and other culture that produces different art deco typologies in three different areas in Surakarta.With different backgrounds, the absorption and adaptation of Art Deco style in residential houses in each region is different. But the common thread is the absorption of several styles, namely: Java, Art Deco, Art Nouveau, Middle East, and China which finally created the eclectic Art Deco style.
\end{abstract}

Keywords: Art deco; architectural character; comparative studies.

\section{INTRODUCTION}

The form of a region is a unified system consisting of three factors, namely spatial system, physical system, and stylistic system. The social, economic, cultural, political developments of the community are slowly beginning to affect the physical appearance of a wakeful environment, including in residential homes. One of the phenomena that occurred in Surakarta in the early 19th century was the development of residential buildings that adopted Art Deco style. Art Deco emerged from the change of thinking patterns of a group of people who one of them backed from the establishment of the economy. Each region that receives Art Deco styles develops itself, giving local touch, so Art Deco somewhere will be different from Art Deco elsewhere.

In the city of Surakarta, there are areas that get influence of Art Deco style, among others: Baluwarti, Laweyan, and Kauman. Baluwarti is a settlement for Courtiers and their Servant of Kasunanan Palace. Laweyan is a settlement for Batik Entrepreneur in Surakarta. While Kauman is a Settlement for Religion Courtiers (Ulama) of Kasunanan Palace. With different backgrounds, the absorption and adaptation of Art Deco style in each object of study is different. The problem in the object of study is the absorption and adaptation of elements of Javanese culture and others culture that produce different art deco typology in each object of study. Therefore, this study aims to compare the absorption and adaptation of elements of Javanese culture and others culture that produces different art deco typologies in three different areas in the city of Surakarta.

\section{DEFINING ART DECO STYLE}

Excerpted from Johana (2004 in Solikhah, 2017), Art Deco Architecture in addition to receiving historical ornaments, this style also received the influence of the flow of architecture that was developing at the time, namely: Bauhaus, De Stijl, Dutch Expressionism, International Style, Rationalism, Scandinavian Romanticism and Neoclassicism, Arts and Crafts Movement, Art Nouveau, Jugendstil and Viennese Secession. They also influence the formation of Art Deco architecture and provide modern touches. Modern at that time defined by "daring to be different and new, appearing more attractive than others and not ancient" all of which are manifested by striking color choices, unusual proportions, new materials and decorations.

At The beginning of the 21 st century the Art Deco style enjoys popularity unrivalled since its inception at the 1925 Exposition Internationale des Arts Decoratifs et Industriels Modernes in Paris (Tinniswood, 2002). Since then the name of Art Deco is used for Named art that was popular and modern. The emergence of that terminology in some articles increasingly made the name of Art Deco a place in the art world with the publication of the book "Art Deco" by Bevis Hillier in America in 1969. Art Deco is one of the very widely applied styles, various examples we can find, in Architecture, clothing, posters and household appliances as well as many other examples. Although there are a variety of objects that use Art Deco style, but it is not easy to define how the Art Deco style. Popular themes in Art Deco are trapezoidal, zig-zag, geometric, and puzzle 
forms, ornaments that are used more regularly and use many lines or squares. Every country that receives Art Deco style develops itself, giving local touch so Art Deco somewhere will be different from Art Deco elsewhere (Johana, 2004 in Solikhah, 2017).

Excerpted from Nas (2009), Art Deco Building in Indonesia is better known as Indies building (Indische Landhuizen) because it has elements of culture and climate in Indonesia. Excerpted from Widyarta (2012), the definition of a single Indies society through the synthesis between elements of Eastern and Western cultures. Suryokusumo and Suryasari (in Indartoyo, 2008) conclude that as the beginning of the development of the Colonial Architecture in Indonesia is the Indies Architecture. Subsequent developments were marked by the appearance of Niuew Bouwen Architecture, where the architectural styles that flourished were modern architectural styles, including the Art Deco style inside.

\section{METHODOLOGY}

The type of study that used is comparative studies in the form of explorative description of the absorption and adaptation of Art Deco style on the residence in the object of study. Descriptive method focuses on finding facts as to actual circumstances (Moleong, 2005: 14). The scope of study area are Kampong Laweyan, Kampong Baluwarti, and Kampong Kauman in Surakarta city (fig. 1). While the scope of the substance is the assessment of the absorption and adaptation of Art Deco style in residential houses in each region. Selection of sample and respondent is done by purposive sampling with criterion of residence in scope of study area which have character of Art Deco and have got recommendation from resource person, that is:

a. Residence of M. Asngad's family (formerly home of Tjokro Handoko) on Jl. Dr. Rajiman Number 473, Laweyan, Surakarta

b. Residence of Hj. Aisiyah's family (Bakri Zaed) in Gambuhan RT/RW. 01/03 Number 30, Baluwarti, Surakarta

c. Residence of $\mathrm{Hj}$. Qisti Mas'adi's family on $\mathrm{Jl}$ Wijaya Kusuma Number 28, Kauman, Surakarta

The requirement factor to be studied is fixed, where the condition of the indicator can not be changed and as a characteristic of each object which will function as a parameter (Fletcher, 1963). The factors that studied are the historical background and the embodiment of absorption and adaptation of Art Deco style (Architectural Character) in the residence of a stylistic system that embodies the form, including: fasade, roof, wall, column, opening, and decoration (excerpted from Setyaningsih, 2004). Furthermore, these factors will be analyzed in each object of study with explorative description method so that it can be known the absorption and adaptation of Javanese cultural elements and others cultures that produce different art deco typology in three different areas in the city of Surakarta.

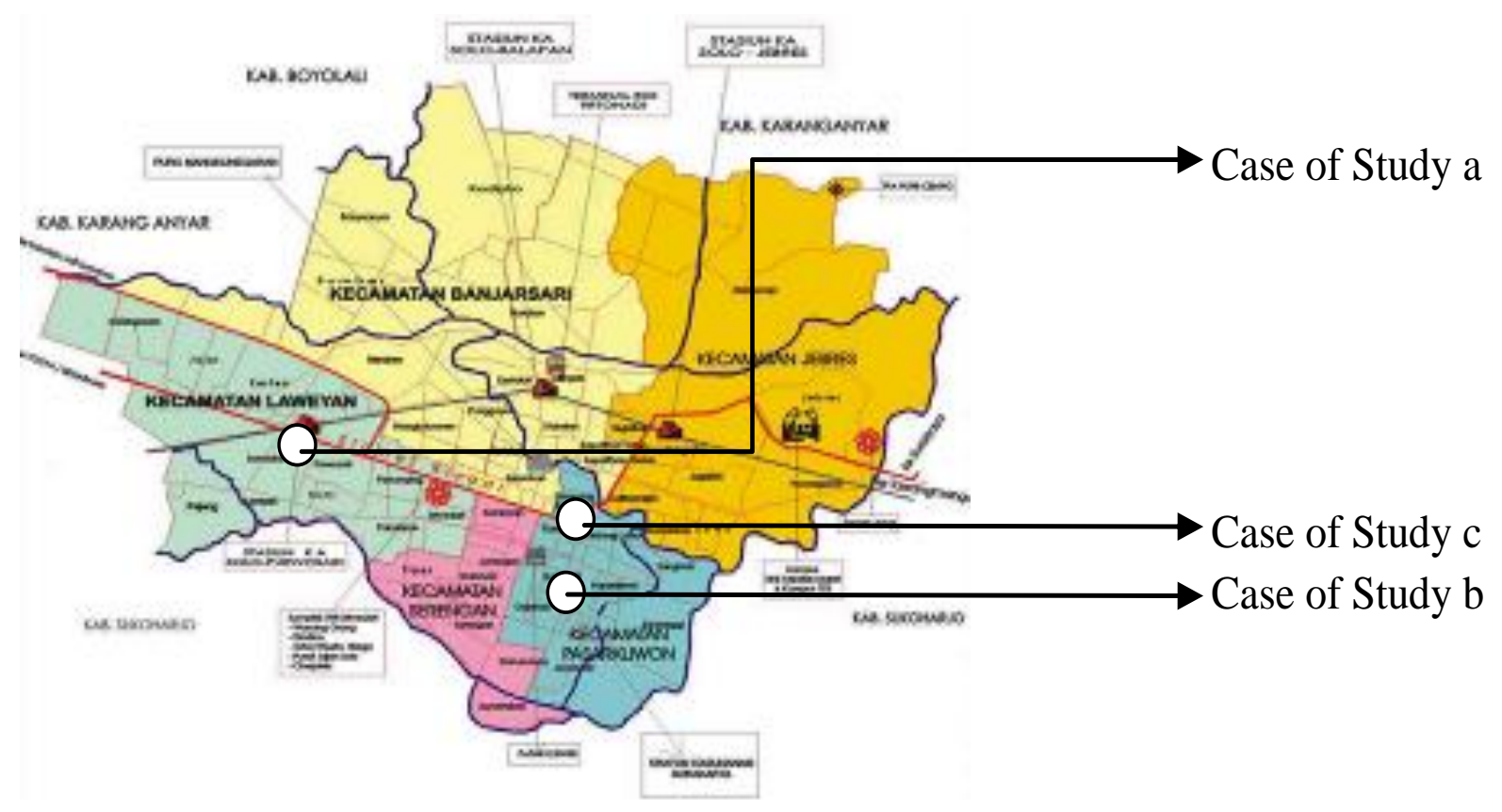

Fig. 1. Location Case of Study on Surakarta's City Map (Source: http://dprd.surakarta.go.id/selayang-pandang/, 2017) 


\section{DISCUSSION}

\section{Art Deco in Laweyan}

\section{History of Kampong Laweyan}

Based on interview with Mr. Muqoffa (March, 2017), Laweyan is settlement of Batik entrepreneur in Surakarta. The name Laweyan has existed since the founding of the Nagari Surakarta Hadiningrat in 1745. In its development, most of the architectural buildings in Laweyan are the result of acculturation by local people through the presence of European, Middle East and Chinese characters due to the high sociability and economic ability that allows Laweyan residents to visit to some parts of the world. One of the important things is the experience of Hajj pilgrimage that allows the interception with the outside culture.

\section{History of Residence of M. Asngad's Family}

Residence of M. Asngad's family located on Jl. Dr. Rajiman No. 473, Surakarta was built in 1955. It is seen from the symbol of the year that became the ornament on some glass and wall of the house. This house was formerly owned by Tjokro Handoko, a successful Batik and Bus businessman in Laweyan and a close associate of Ir. Soekarno (first President of Republic of Indonesia), then in 1977 this house was bought by a textile entrepreneur named Mr. Sanusi. Today the house is inhabited by Mr. M. Asngad's family (the first child of Mr. Sanusi).

\section{Absorption of Art Deco}

\section{a. Organization of Space}

Kampong Laweyan is a Kampong that older than Kasunanan palace, so that the interaction of middle to upper class citizens more oriented to Europe, Middle East, and Chinese. Residence of M. Asngad's family was built in 1955 in the Late Art Deco period with the organization of space which is more referring to European style houses, it shows that the absorption of Art Deco style is more influenced by the wide social circles with Europe, the East Central, Chinese. Although Tjokro Handoko is a batik entrepreneur, but the production site is located on different land (fig. 2).

\section{b. Fasade}

The facade uses a geometric zig-zag precolumbian style to form rhythmic irregularly patterns as the influence of Art Deco styles. The influence of the period of Late Art Deco/ Streamline (1930-1950) is seen in the overstek of the building facade which is arranged horizontally elongated to form a dominant streamline on the facade of the building (fig. 3).

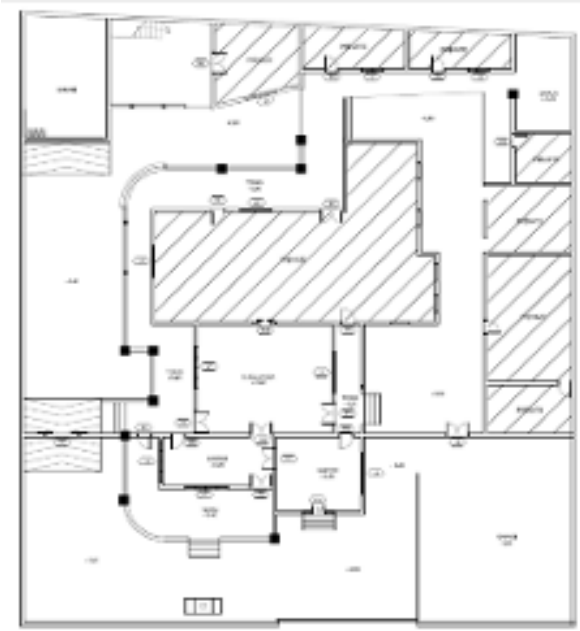

Fig. 2. Organization of Space of M. Asngad's Family Residence (Source: Redraw by Author based on Primary Survey, 2017)
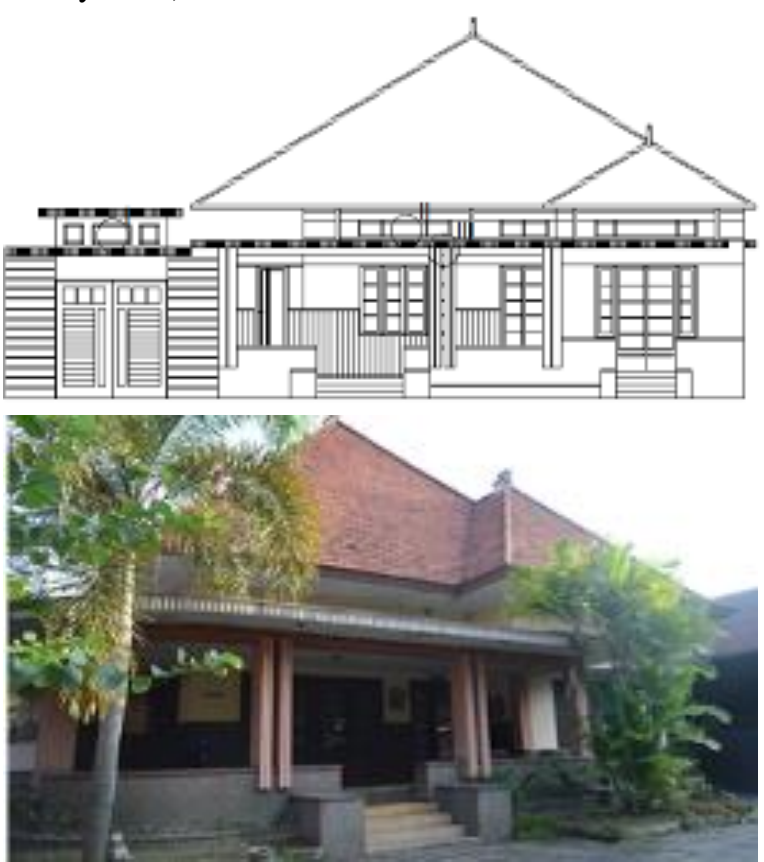

Fig. 3. Fasade of M. Asngad's Family Residence (Source: Redraw by Author based on Primary Survey, 2017)

\section{c. Roof}

The roof of the building uses a pyramid roof with a tile cover material to adjust the local climate combined with a flat roof of concrete material as a adoption of colonial-style of the 1920s. Massive walls on the roof of the building using geometric zig-zag 
pre-columbian style. The use of elements of the Dutch East Indies colonial architecture between the 1900s and 1920s took the form of acroteric jewelry on the edge of the roof ridge with a curved geometric style. The roof of the building was also influenced by the style of Nieuwe Bouwen from 1915 to 1960 through the use of modern materials and construction methods in the form of non concrete use (fig. 4).

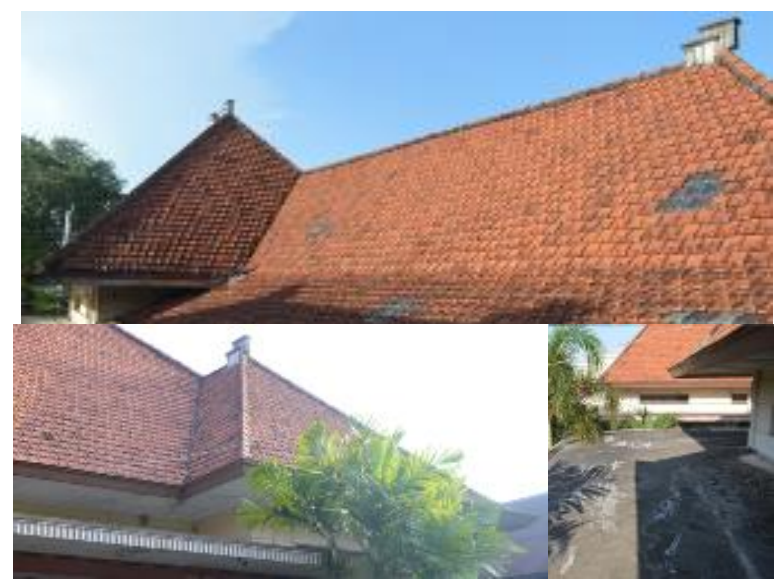

Fig. 4. Roof of M. Asngad's Family Residence (Source: Primary Survey, 2017)

\section{d. Wall}

The walls of the house are made of plaster and fine-textured bricks. There are several variations of wall coating, namely: coated paint, coated wood (parquete), coated with natural stone, geometric motive (fig. 5). On the inner wall of the main room and the living room half of the wall is lined with wooden sheet (parquete).
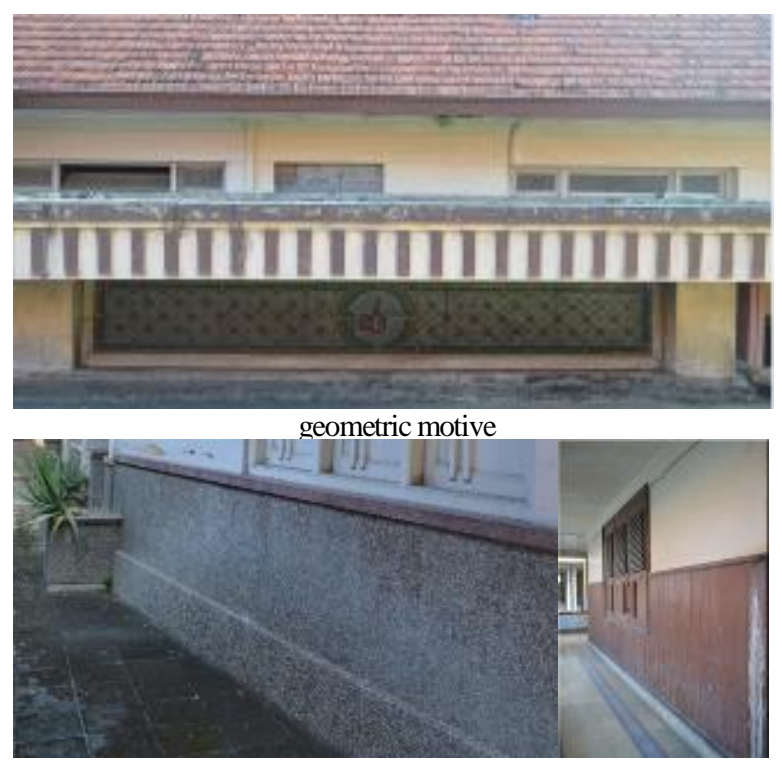

coated with natural stone

parquete

Fig. 5. Walls of M. Asngad's Family Residence (Source: Primary Survey, 2017)

\section{e. Colomn}

Columns become elements that reinforce the influence of Art Deco in residence of M. Asngad's family. This can be seen from the use of twin column on the exterior of the building. The influence of the Late Art Deco/ Streamline period (1930-1950) is seen in the use of vertical line planes so as to form a vertical streamline on the building column (fig. 6).

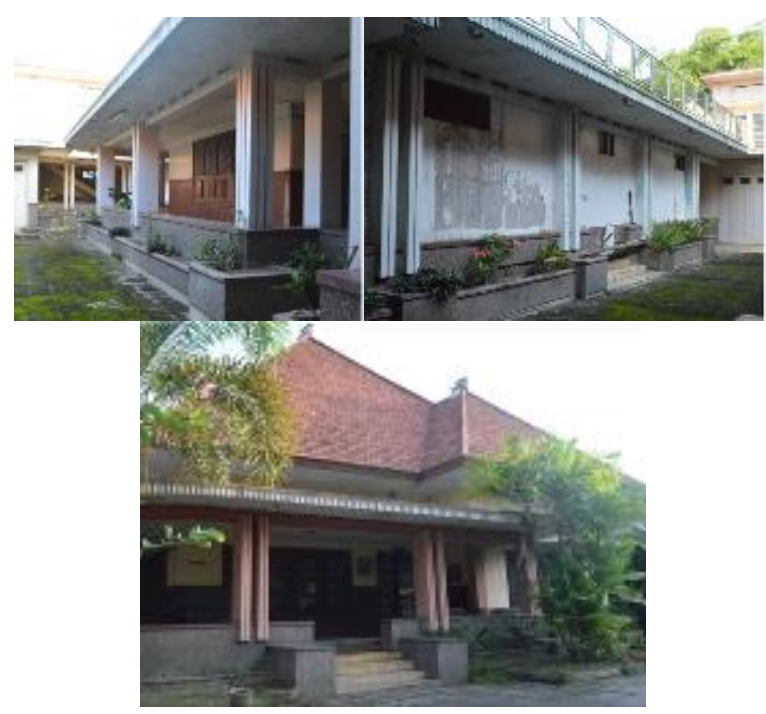

Fig. 6. Colomn of M. Asngad's Family Residence (Source: Primary Survey, 2017)

\section{f. Opening}

Bovenlicht above the door/ window using ice glass ornaments with symbol "thumbs up" which is a logo of business Tjokro Handoko and "1955" which shows the year of making the house. The windows get Art Deco influences through the use of brown teak paneled panels and filled with geometric patterned iron rods with an uniformly pointed composition of arrows. The influence of Art Deco lies in the espose of wood material with geometric motives (fig. 7).

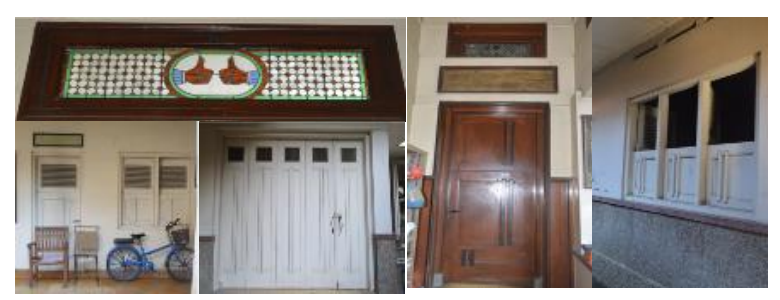

Fig. 7. Opening of M. Asngad's Family Residence (Source: Primary Survey, 2017)

\section{g. Decoration}

The decoration of residence of M. Asngad's family is formed by colorful tiles, the use of iced glass 
with "thumb" \& "1955" symbols, and the unity of geometric motives that characterize the Art Deco building (fig. 8).

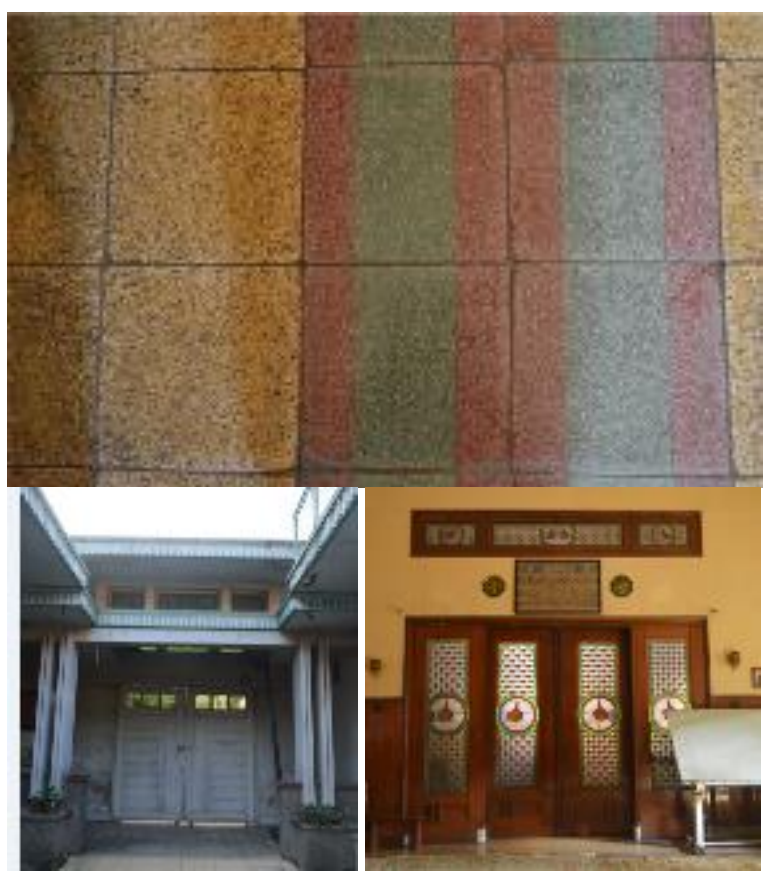

Fig. 8. Decoration (Floor) of M. Asngad's Family Residence (Source: Primary Survey, 2017)

\section{Art Deco in Baluwarti}

\section{History of Kampong Baluwarti}

Beteng area in the area of Kasunanan Palace called Baluwarti, derived from the Portuguese baluarte which means a fort because it has a limits (edges) in the form of a fortress. Baluwarti was originally a residence area of Courtiers and their servant of Kasunanan Surakarta with two district patterns, the pattern of dalem and settlement patterns. Pattern dalem form a house (dalem) with a large yard surrounded by a wall of yard. While the settlement pattern began to be provided by PB III in 1755 in the form of a group of houses for the Courtiers in one profession (Farkhan, 2004: 456 in Solikhah, 2012).

Baluwarti arrangement is structured based on functional and symbolic-spiritual conceptions. The symbolic-spiritual pattern is seen in north-south orientation and imaginary circle based on the gradation of sanctity, where the Palace as a central. In a functional conception, Baluwarti's environmental order was established to support the existence of the Kasunanan Palace. Settlement activities related to the profession of the Courtiers (Farkhan, 2004: 456, in Solikhah, 2012). With the development of the type of economic activity and increasing the economic level of Baluwarti residents, then we can find the typology of Javanese-European-Chinese-Islamic mixed house style.

\section{History of Residence of Hj. Asiyah's Family (Bakri Zaed's Family)}

One of the citizens of Baluwarti who experienced a rapidly increasing economy was Nyai Zaed, through efforts in the field of weaving, yarn (lawe) based woven materials-, tobacco, and wenter (dye fabric). Her business experienced rapid development in the 1950s by opening several stalls in Pasar Gedhe. To show her existence and social status, she began to renovate her residence in the Kampong Baluwarti. Influenced by a wide range of associates with batik merchants from Laweyan and Kauman as well as business associates from Chinese people at Pasar Gedhe, her residence was heavily influenced by Art Deco and Indisch houses that already exist in Laweyan and Kauman areas of the early 19th century. In addition, the adaptation of Chinese architecture also influences the decoration of the living quarters of Nyai Zaed (now occupied by Bakri Zaed's family). The initial design of the residence uses the services of a Chinese descendant architect named Alay, but the role of the architect does not dominate. Nyai Zaed did not hesitate to adopt a variety of ornamental architectural styles that are or ever trend, such as Art Deco, Indisch, and Art Nouveau (Interview with Faizah-the youngest daughter of Bakri Zaed -, 2012).

\section{Absorption of Art Deco}

\section{a. Organization of Space}

Although located in Kasunanan Palace area, but the organization of space in the residence of $\mathrm{Hj}$. Aisiyah's family does not refer to the organization of Javanese house used in Dalem Pangeran residence located in Surakarta palace but actually refers to the organization of European-Chinese living room (fig. 9). This shows that the absorption of Art Deco is more influenced by the wide circle of association with batik merchants from Laweyan and Kauman as well as business associates from Chinese people around Pasar Gedhe.

\section{b. Fasade}

The facade uses a geometric zig-zag pre-columbian style to form rhythmic irregularly patterns as the influence of Art Deco styles. The influence of the period of Late Art Deco/ Streamline (1930-1950) is seen in the overstek of the building facade which is arranged horizontally elongated to form a dominant streamline on the facade of the building (fig. 10). 


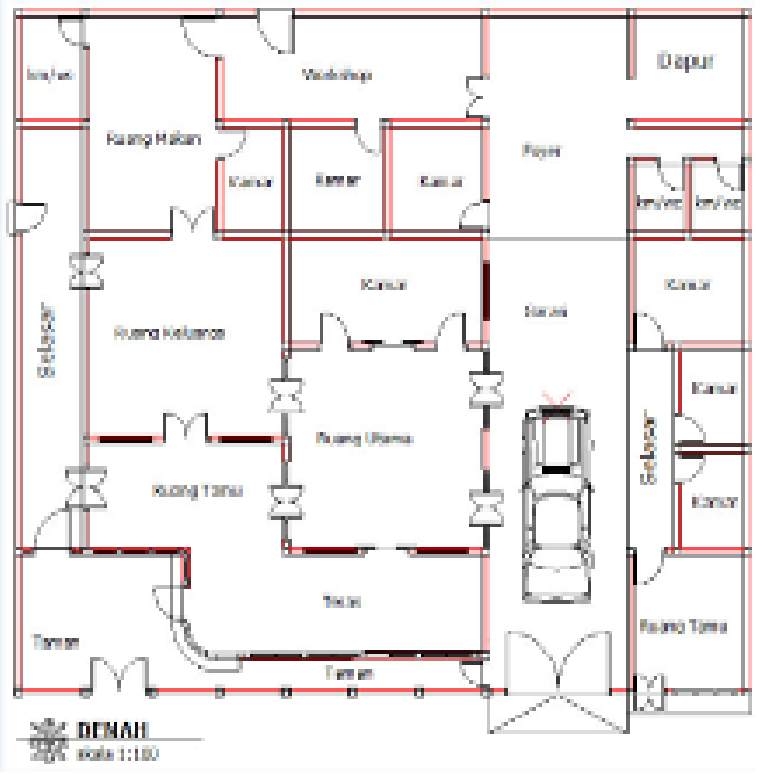

Fig. 9. Organization of space of $\mathrm{Hj}$. Aisiyah's Residence (Source: Redraw by Author based on Primary Survey, 2017)

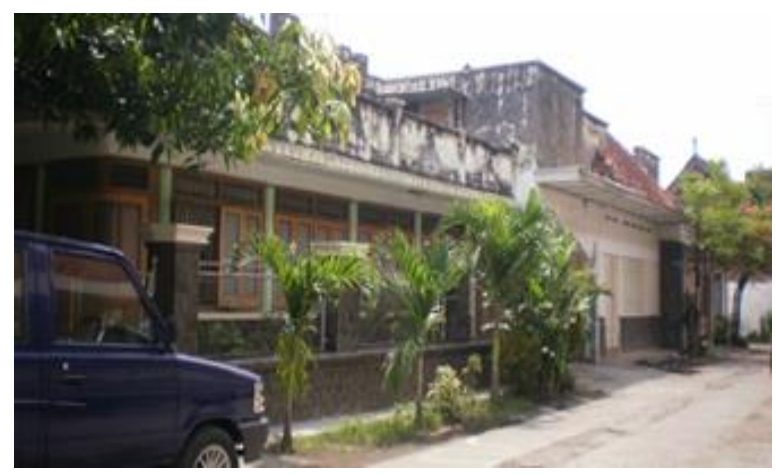

Fig. 10. Fasade of Hj. Aisiyah's Residence (Source: Primary Survey, 2017)

c. Roof

The roof of the building uses a pyramid roof with a tile cover material to adjust the local climate combined with a flat roof of concrete material as adoption of a colonial-style of the 1920s. Massive walls on the roof of the building using geometric zigzag form as the influence of Art Deco style. The shape of this ornament tends to be rigid and angular. The use of elements of the Dutch East Indies colonial architecture between the 1900s and 1920s took the form of acroteric jewelry on the edge of the roof ridge with a curved geometric motive. In addition to the dominance of Art Deco influence, the typology of building roof is also influenced by Nieuwe Bouwen style from 1915 to 1960 period through the use of modern materials and construction method in the form of non concrete use (fig 11).

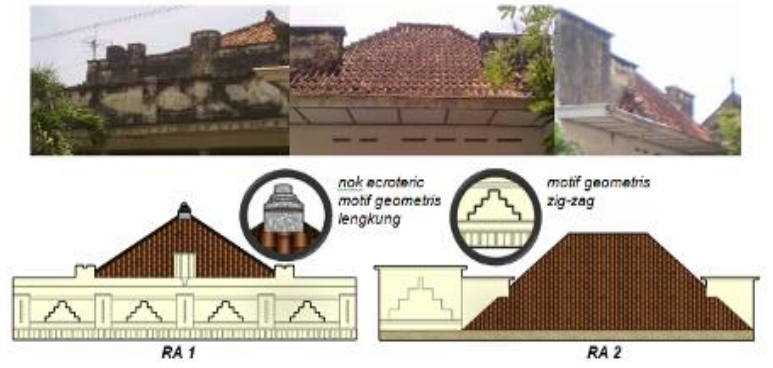

Fig. 11. Roof of Hj. Aisiyah's Residence (Source: Solikhah, 2012)

\section{d. Wall and Column}

The walls of the house are made of plaster brick, finely textured, and coated with light green-and-white paint. On the wall in the main room and family room there is a decoration of the inner wall 1 in the form of a geometric pattern of repetition with a combination of green color typical of the Middle East. The lower part of the wall in the main room is covered with $20 \times 20 \mathrm{~cm}$ ceramic with combination motive and composition pattern. The inner wall decoration 2 and the decoration of the inner wall 3 using a combination of geometric, natural, stylactic, or medallion-shaped motives as the influence of the Dutch colonial style. The influence of Art Nouveau is characterized by leaf-stylized motives and leaf-shaped curved shapes. The influence of Chinese motives is found in the natural pattern of red flowers. At the bottom of the Wall there is a green geometric motive as an adaptation of Middle Eastern architecture. On the outer wall there is an adaptation of dorik columns with plain motives and a combination of light green and white. The influence of Art Deco is found in the decoration of outer walls 2 in the form of natural stone stone espose times (fig. 12).

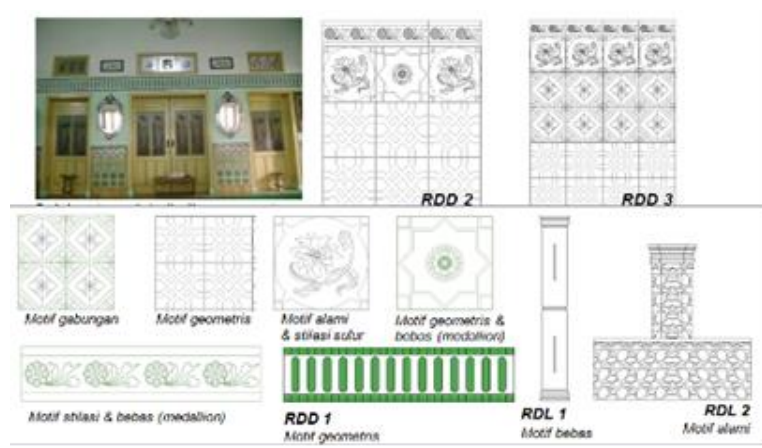

Fig. 12. Walls and Colomns of Hj. Aisiyah's Residence (Source: Solikhah, 2012)

\section{e. Opening}

\section{Doors and Windows}

The decorative character of the doors-windows varies to indicate the function of space. Decorative 
doors and windows use the 1950s colonial type by removing ornaments, geometric decoration, and straight detail. Doors and windows match the colonial type of vertical plane with teak wood and the use of ice glass without motive. The colors of the doors use a combination of ivory yellow and light green. Geometric motives on the leaves of the doors are arranged with a pattern of composition.

Variety of decorative window 2 get Art Deco influence through the use of brown teak panel and filled with geometric trellis iron rods with a regular composition that led to arrows. Door 4 decoration using wood and glass with natural motives in the form of a combination of flora-fauna motives are arranged with a pattern of stuffing as an influence of Chinese culture brought by the architect of Bakri Zaed's family home. Panel and door leaves are coated with ivory yellow paint, while on natural motives use red and green.

Decorative of door 5 , door 6 , door 7 , door 8 , and window 3 using 1950s colonial type by removing ornaments, geometric decoration, and straight detail, door and window in the field of vertical with wood material teak. The effect of Art Deco lies in the espose of wood material with geometric motives and the use of ivory yellow (fig. 13).

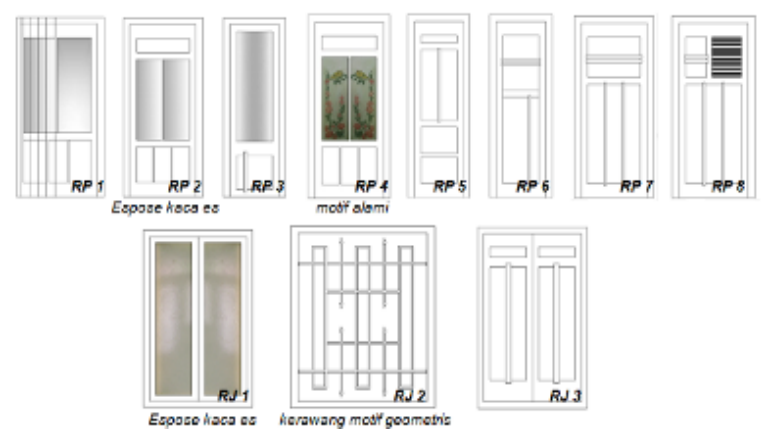

Fig. 13. Opening of of $\mathrm{Hj}$. Aisiyah's Residence (Source: Solikhah, 2012)

\section{Bovenlicht}

The influence of the colonial style of the $1950 \mathrm{~s}$ on bovenlicht in the form of combinations of materials, motives and patterns of decoration. Bovenlicht on the main entrance as decoration bovenlicht 1 using brown teak panel. Teak wooden brown wooden filigree is arranged using irregular field pattern with geometric motive of horizontal field. While bovenlicht above the window lined on the terrace as decorative bovenlicht 2 get Art Nouveau influence. Bovenlicht 2 uses teak panel and filled with iron bars with combined motives, namely geometric motives and stilt-shaped curved tendrils motives equipped with ice glass without motive (fig. 14).

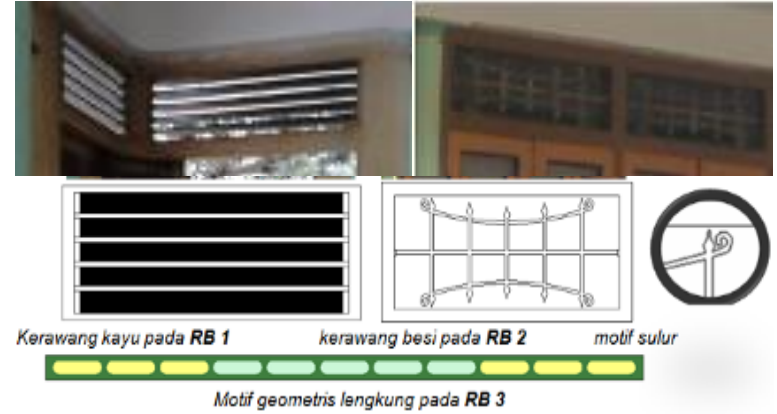

Fig. 14. Bovenlicht of Hj. Aisiyah's Residence (Source: Solikhah, 2012)

\section{f. Decoration}

Excerpted from Solikhah (2012), Typology of decoration of $\mathrm{Hj}$. Aisiyah's family home is the absorption and adaptation of Javanese and others cultural elements. Adaptation of the concept of pendhapa at the height of the floor is the influence of Javanese cultural elements applied to the floor height. Adaptation of Art Deco element to massive wall of building roof with geometric zig-zag motive of precolumbian style is trapezoid, natural stone motive which is diespose, and the use of strong colors. Absorption of the Art Nouveau element as a decorative character in the form of a leaf-shaped curvature. Absorption of Colonial element on nok acroteric with curved geometric motive, use of concrete, eliminating ornament, geometric line decoration as motive, completion of detail, door and window of vertical field with teak wood, and medallion ornament. Geometric motive patterned looping with a combination of green color is a typical Middle Eastern motive adaptation. Adaptation of Chinese elements in the form of ice glass with a combination of flora-fauna motive coated with red and green paint.

\section{Art Deco in Kauman}

\section{History of Kampong Kauman}

Summarized from Pusponegoro (2007), Kampong Kauman in Surakarta has a relationship with the existence of Kasunanan Palace Surakarta along with the establishment of Surakarta Great Mosque by Paku Buwana III in 1757. The mosque was built by the king as a form of obligation of the King in leading his people where the King as Sayyidin Panatagama Khalifatullah, which means king in addition to being the leader of the state (kingdom), the king is also a religious leader for the people to live in peace and prosperity. To perform the duties of Sayyidin Panatagama Khalifatullah, the king appointed and placed a penghulu (an expert in the field of religion as well as 
adviser to the king) in the mosque, and the penghulu also given the right to use on a plot of land located in the north of the mosque.

The birth of the Kampong Kauman started with the placement of a servant of Pamethakan duty in charge of religious and mosque, namely Kanjeng Kyai Penghulu Mohammad Thohar Hadiningrat who settled around the Great Mosque. Penghulu oversees the land around the mosque whose citizens are composed of servants Pamethakan and ulama as a helper/representing the duty of Penghulu if penghulu absent. The land he occupies is a gift from Paku Buwana III with the status of land Anggaduh, which means only entitled to occupy and have no property rights. By the Palace, the land is named Perkauman, meaning the land where the clans live, and become Kauman.

Excerpted from RM. Sajid (In Pusponegoro, 2007), it can be concluded that the existence of the Kauman village existed because it was desired by Paku Buwana III as the King as part of the four components of the pattern of Islamic government city that consists of: Keraton, Alun-alun, Masjid, and Market.

\section{History of Residence of Hj. Qisti Mas'adi's Family}

Residence of Hj. Qisti Mas'adi's family (formerly home of H. Abu Amar, Kyai/ Religious leader/ Batik Entrepreneur) in Jl Wijaya Kusuma number 28, Kauman has a land area of $899 \mathrm{~m} 2$, building area 750 $\mathrm{m} 2$, built in $1856 \mathrm{M}$. Currently the building has not been too many significant changes (relatively original). Excerpted from Musyawaroh (in Pusponegoro, 2007). House of $\mathrm{Hj}$. Qisti Mas'adi was built in 1828, the figure was once inscribed on the inside wall of the house which has now been shelled replaced by a new one. However, according to the landlord, the number 1828 may be the year of Java, or if used as BC is $1898 \mathrm{M}$.

\section{Absorption of Art Deco}

\section{a. Organization of Space}

The residence of $\mathrm{Hj}$. Qisti Mas'adi is a house built by batik entrepreneurs and doubles as a living place and place of batik business (production to sales). Space organization refers to the house/Dalem of Courtiers in Kasunanan Palace Surakarta because they are descendants of the religious leader of Kasunanan Palace (fig. 15).

Organizations of space of traditional Javanese house commonly used in Dalem Pangeran dwellings generally consist of: courtyard, pendapa, ndalem (complete with left senthong, right, center) and partly added with gandok and pringgitan. Also equipped with a lojen located in front or side of the house. While the organization of space Object 3 is: courtyard (front/ side/ back), dalem complete with senthong leftmiddle-right and factory. Currently Object 3 is still original as at the beginning of construction complete with factories located at the back of the house, but the condition is less well maintained and the factory left unused.

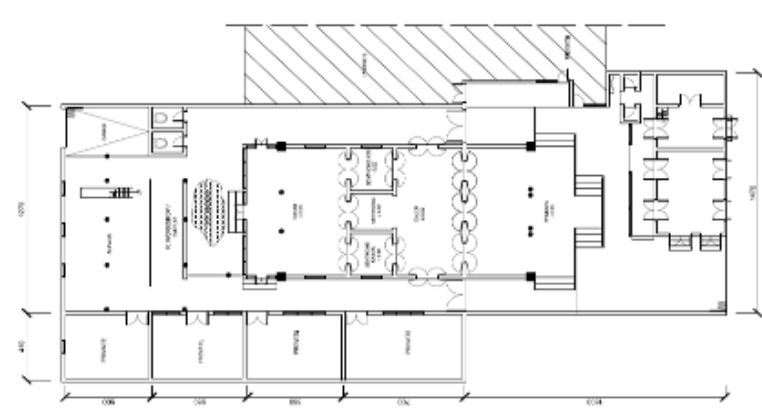

Fig. 15. Organizatin of space of $\mathrm{Hj}$. Qisti Mas'adi's Residence (Source: Redraw by Author based on Primary Survey, 2017)

\section{b. Fasade}

The facade of is a blend of traditional Javanese with Europe. Javanese architectural features seen in the open pavilion and limasan roof used. The European elements are applied to building ornaments such as: roof gable, lambrissering, columns, poles, etc. Height of Object 3 is $\pm 7 \mathrm{~m}$, with a building span of $1-1.5 \mathrm{~m}$ from its height, so the building is impressive high and dashing. The ornaments or decorations found in the housemaid describe the social status of the owner. The more beautiful and intricate ornaments, the richer the owner of the house. The absorption of Art Deco can be seen in the Lojen facade which uses geometric zig-zag motive (fig. 16).

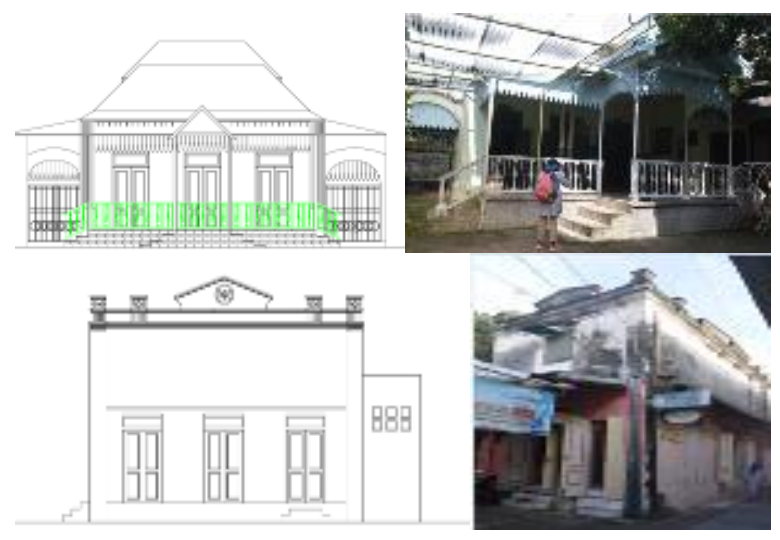

Fig. 16. Fasade of Hj. Qisti Mas'adi's Residence (Source: Redraw by Author based on Primary Survey, 2017) 
c. Roof

The roof of the building uses a pyramid roof with a tile cover material to adjust the local climate combined with a flat roof of concrete material as a colonial-style adoption of the 1920s. Massive walls on the roof of the building using geometric motives zig-zag pre-columbian style as the influence of Art Deco style (fig. 17).

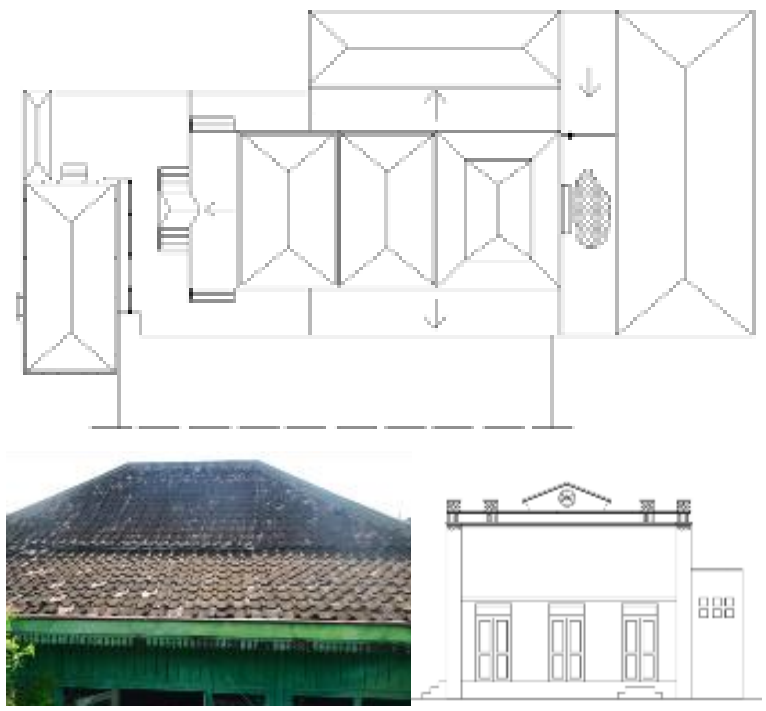

Fig. 17. Roof of Hj. Qisti Mas'adi's Residence (Source: Redraw by Author based on Primary Survey, 2017)

d. Wall

The dividing wall on the side of the pendapa is composed with the opening plane, tritisan pole, lambrissering, ornamented iron balustrade, floor/ trap rise and roof gable. Some parts of the wall use geometric motives (fig. 18).
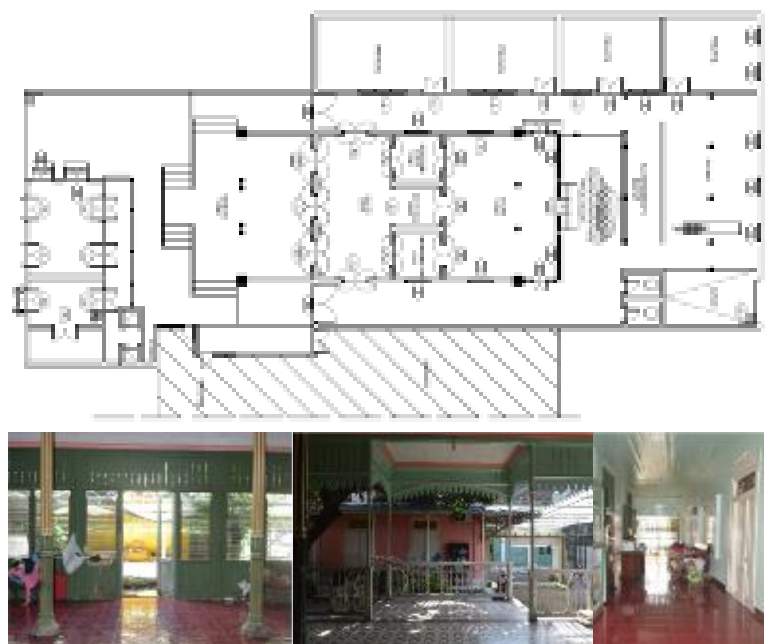

Fig. 18. Wall of Hj. Qisti Mas'adi's Residence (Source: Primary Survey, 2017) e. Column

The wooden pillars supporting the roof of the terrace on the pavilion are decorated with Art Deco Classicism carved with paint and prada to accentuate the luxurious and expensive impression (fig. 19).

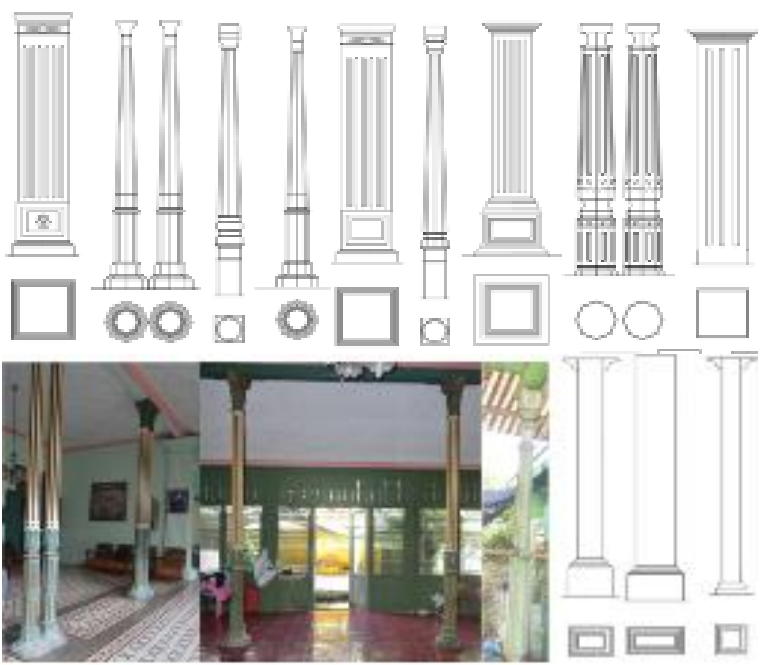

Fig. 19. Colomns of Hj. Qisti Mas'adi's Residence (Source: Redraw by Author based on Primary Survey, 2017)

\section{f. Opening}

Bovenlicht above the door/window using ornaments carved wood carving spirals. The windows get Art Deco influences through the use of brown teak paneled panels and filled with geometric patterned iron rods with an uniformly pointed composition of arrows. The effect of Art Deco lies in the espose of wood material with geometric motives and the use of ivory yellow (fig. 20).

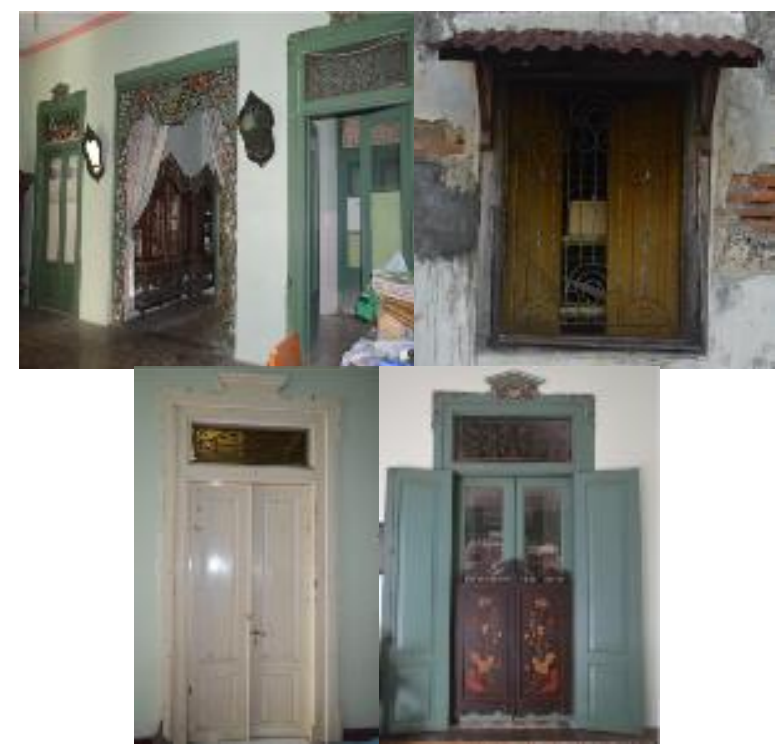

Fig. 20. Opening of Hj. Qisti Mas'adi's Residence (Source: Primary Survey, 2017) 


\section{g. Decoration}

Decorative Variety at Residence of $\mathrm{Hj}$. Qisti Mas'adi's family one of them in the form of the use of colorful tiles that impress the impression of luxury and expensive. At this time some parts of the building have been replaced with ceramics because there are old floor that has been damaged and the floor surface is declining (fig. 21).
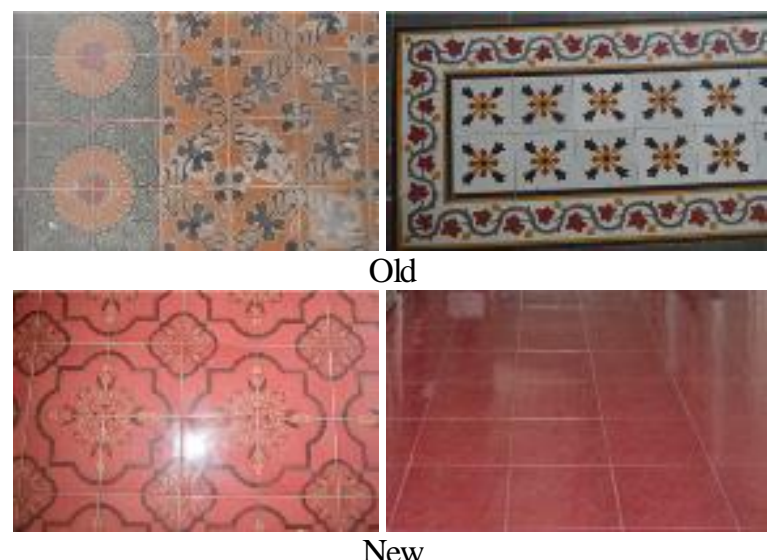

Fig. 21. Decoration (Floor) of Hj. Qisti Mas'adi's Residence (Source: Primary Survey, 2017)

\section{CONCLUSION}

Background of the history of the area that gained the influence of Art Deco style in Surakarta City, namely: Baluwarti is settlement for Courtiers and their servant of Kasunanan Palaces, Laweyan is settlement of Batik entrepreneur in Surakarta, while Kauman is the settlement for Religion Courtiers (Ulama) of Kasunanan Palace. With different backgrounds, the absorption and adaptation of Art Deco style in residential houses in each region is different. But the common thread is the absorption of several styles, namely: Javanese, Art Deco, Art Nouveau, Middle East, and China that finally created the eclectic Art Deco style.. There are no standard characters and styles. The process of absorption based on the taste of the owner as a form of self-existence that is influenced by social status, economic level, social culture/politics (associated with Kasunanan and Pura Mangkunegaran), and social circles.

\section{ACKNOWLEDGMENT}

This paper is an outcome of Kemenristekdikti Grant in Dosen Pemula Scheme Fiscal Year 2017. We give our thank you specifically to:

a. Directorate of Research and Community ServiceDirectorate General for Research and Develop-
ment-Ministry of Research, Technology and Higher Education in accordance with the contract of Research Number: 0407 / K3 / KM / 2017 , Date May 24, 2017 with the title of Research: Penyandingan Bangunan Art Deco Di Kota Surakarta (Studi Kasus: Rumah Tinggal Di Laweyan, Baluwarti, Kauman)/ Comparison of Art Deco Building In Surakarta City (Case Study: Residence In Laweyan, Baluwarti, Kauman).

b. Director of Research and Community Service Universitas Tarumanagara in accordance with the Research Contract of Lecturers of Fiscal Year 2017 Number: 504-SPK-DIR. PPKM / Untar / VII / 2017 dated July 10, 2017

c. A resource person: Dr. (Hon). Ark. Djauhari Sumintardja, Dipl. Bldg. Sc., Dr. Ir. M. Muqoffa, M.T., H. Gunawan Setiawan, S.E., M.M., Hj. Aisiyah Bakri Zaed, Hj. Qisti Mas'adi, Mr. M. Asngad, S.T., M.T.

d. Surveyor Team: Joerynda P. Wijayakusuma, Alifia Lufthansa, Mega Dwi Kusumawati.

e. And to all parties who have helped this research.

\section{REFERENCES}

Fletcher, S. B. (1963). A History of Architecture on the Comparative Method.The Athlone Press, London.

Indartoyo (2008), Penampilan Bangunan Art Deco yang Dibangun di Indonesia Tahun 1920-1940 dan Bangunan Art Deco Tahun 1985-2005, Prosiding Seminar Nasional Perkembangan Teknologi vs Konservasi Arsitektur, Jurusan Arsitektur Universitas Merdeka Malang, August, $28^{\text {th }} 2008$.

Moleong, L. J. (2005). Metodologi Penelitian Kualitatif. Remaja Rosdakarya, Bandung.

Nas, P. J.M., \& Vletter, M. (2009). Masa Lalu dalam Masa Kini Arsitektur di Indonesia. PT. Gramedia Pustaka Utama, Jakarta.

Pusponegoro, M., et al. (2007). KAUMAN: Religi, Tradisi, dan Seni. Paguyuban Kampung Wisata Batik Kauman, Surakarta.

Setyaningsih, W. (2004) Tata Ruang Dalem Pangeran di Baluwarti Surakarta. Jurnal RUAS-Architecture and Urban \& Regional Planning Department, Faculty of Engineering, Brawijaya University, 2(1), 33-41.

Solikhah, N. (2012). Tipologi Ragam Hias Rumah Tinggal Keluarga Bakri Zaed di Baluwarti Surakarta, Jurnal TESA Universitas Katolik Soegijapranata Semarang, 10(1), 18-28. (http://journal.unika.ac.id/index.php/tesa/article/ view/11). 
Solikhah, N., \& Kurnia, A. S. (2017). Development of Art Deco Architecture in Indonesia, Proceeding of The 3rd International Conference on Engineering of Tarumanagara (ICET) 2017, Faculty of Engineering, Tarumanagara University, Jakarta-Indonesia, October 4-5th, 2017.
Tinniswood, A. (2002). The Art Deco House. Octopus Publishing Group Ltd., London.

Widyarta, M. N. (2012). Tampilan Hindia Melalui Arsitektur. Tegang Bentang: Seratus Tahun Perspektif Arsitektral di Indonesia, Pusat Dokumentasi Arsitektur. PT. Gramedia Pustaka Utama, Jakarta. 